\title{
PERKEMBANGAN EKONOMI KOPERASI di INDONESIA
}

\author{
Camelia Fanny Sitepu ${ }^{1)^{*}}$, Hasyim ${ }^{2)}$ \\ 1) Fakultas Ekonomi, Universitas Negeri Medan \\ Email: cameliasitepu40@gmail.com \\ ${ }^{2)}$ Fakultas Ekonomi, Universitas Negeri Medan \\ Email: mashasyim4@gmail.com
}

\begin{abstract}
Abstrak
Perkembangan ekonomi di Indonesia dimulai dari masa penjajahan Belanda sampai Jepang. Banyak sekali kesulitan dan penderitaan rakyat pada saat itu,belum lagi mereka harus menuruti kemauan para penjajah. Disini perkembangan ekonomi sangat sulit,karena mereka menguasai semua yang ada. Sampai akhirnya masyarakat mendirikan koperasi kredit dengan tujuan membantu rakyatnya yang terjerat hutang dengan rentenir. Dengan demikian, masyarakat mengenal koperasi serta fungsinya dari koperasi tersebut. Cita-cita Koperasi memang sesuai dengan susunan kehidupan rakyat Indonesia. Meski selalu mendapat rintangan, namun Koperasi tetap berkembang. Seiring dengan perkembangan masyarakat, berkembang pula perundangundangan yang digunakan. Perkembangan dan perubahan perundang-undangan tersebut dimaksudkan agar dapat selalu mengikuti perkembangan jaman. Perkembangan koperasi masih menghadapi masalah-masalah baik di bidang kelembagaan maupun di bidang usaha koperasi itu sendiri. Masalah-masalah tersebut dapat bersumber dari dalam koperasi sendiri maupun dari luar. Masalah kelembagaan koperasi juga dapat dikelompokkan dalam masalah intern maupun masalah ekstern. Masalah intern mencakup masalah keanggotaan, kepengurusan, pengawas, manajer, dan karyawan koperasi. Sedangkan masalah ekstern mencakup hubungan koperasi dengan bank, dengan usaha-usaha lain, dan juga dengan instansi pemerintah.
\end{abstract}

Keywords: Perkembangan Ekonomi, Koperasi, Indonesia 


\section{PENDAHULUAN}

Koperasi merupakan bagian dari tata susunan ekonomi, hal ini berarti bahwa dalam kegiatannya koperasi turut mengambil bagian bagi tercapainya kehidupan ekonomi yang sejahtera, baik bagi orang-orang yang menjadi anggota perkumpulan itu sendiri maupun untuk masyarakat di sekitarnya. Koperasi sebagai perkumpulan untuk kesejahteraan bersama, melakukan usaha dan kegiatan di bidang pemenuhan kebutuhan bersama dari para anggotannya.

Koperasi mempunyai peranan yang cukup besar dalam menyusun usaha bersama dari orang-orang yang mempunyai kemampuan ekonomi terbatas. Dalam rangka usaha untuk memajukan kedudukan rakyat yang memiliki kemampuan ekonomi terbatas tersebut, maka Pemerintah Indonesia memperhatikan pertumbuhan dan perkembangan perkumpulanperkumpulan Koperasi.

Pemerintah Indonesia sangat berkepentingan dengan Koperasi, karena Koperasi di dalam sistem perekonomian merupakan soko guru. Koperasi di Indonesia belum memiliki kemampuan untuk menjalankan peranannya secara efektif dan kuat. Hal ini disebabkan Koperasi masih menghadapai hambatan struktural dalam penguasaan faktor produksi khususnya permodalan. Dengan demikian masih perlu perhatian yang lebih luas lagi oleh pemerintah agar keberadaan Koperasi yang ada di Indonesia bisa benar-benar sebagai soko guru perekonomian Indonesia yang merupakan sistem perekonomian yang yang dituangkan dalam Undang-Undang Dasar 1945.

Cita-cita Koperasi memang sesuai dengan susunan kehidupan rakyat Indonesia. Meski selalu mendapat rintangan, namun Koperasi tetap berkembang. Seiring dengan perkembangan masyarakat, berkembang pula perundang-undangan yang digunakan. Perkembangan dan perubahan perundangundangan tersebut dimaksudkan agar dapat selalu mengikuti perkembangan jaman..

\section{TINJAUAN PUSTAKA}

Perkembangan koperasi di Indonesia terus berkembang. Perkembangan tersebut ditandai dengan banyaknya pertumbuhan koperasi di Indonesia. Tetapi di dalam perkembangan tersebut banyak terjadi hambatan-hambatan. Sebelum mengetahuinya terlebih dahulu kita perlu mengetahui sejarah
NIAGAWAN Vol 7 No 2 Juli 2018

awal pembentukan koperasi. Selain itu, kita juga dapat mengetahui faktor-faktor apa saja yang bisa menghambat pertumbuhan koperasi di Indonesia. Hal ini melatarbelakangi di dalam pembahasan pembuatan makalah koperasi Indonesia. Sampai dengan bulan November 2001, jumlah koperasi di seluruh Indonesia tercatat sebanyak 103.000 unit lebih, dengan jumlah keanggotaan ada sebanyak 26.000.000 orang. Jumlah itu jika dibanding dengan jumlah koperasi per-Desember 1998 mengalami peningkatan sebanyak dua kali lipat. Jumlah koperasi aktif, juga mengalami perkembangan yang cukup menggembirakan. Jumlah koperasi aktif per-November 2001, sebanyak 96.180 unit (88,14 persen). Corak koperasi Indonesia adalah koperasi dengan skala sangat kecil. Satu catatan yang perlu di ingat reformasi yang ditandai dengan pencabutan Inpres 4/1984 tentang KUD telah melahirkan gairah masyarakat untuk mengorganisasi kegiatan ekonomi yang melalui koperasi.

Pengembangan koperasi di Indonesia yang telah digerakan melalui dukungan kuat program pemerintah yang telah dijalankan dalam waktu lama, dan tidak mudah ke luar dari kungkungan pengalaman tersebut. Jika semula ketergantungan terhadap captive market program menjadi sumber pertumbuhan, maka pergeseran ke arah peran swasta menjadi tantangan baru bagi lahirnya pesaing-pesaing usaha terutama KUD. Meskipun KUD harus berjuang untuk menyesuaikan dengan perubahan yang terjadi, namun sumbangan terbesar KUD adalah keberhasilan peningkatan produksi pertanian terutama pangan, disamping sumbangan dalam melahirkan kader wirausaha karena telah menikmati latihan dengan mengurus dan mengelola KUD.

Posisi koperasi Indonesia pada dasarnya justru didominasi oleh koperasi kredit yang menguasai antara 55-60 persen dari keseluruhan aset koperasi. Sementara itu dilihat dari populasi koperasi yang terkait dengan program pemerintah hanya sekitar 25\% dari populasi koperasi atau sekitar 35\% dari populasi koperasi aktif. Pada akhir-akhir ini posisi koperasi dalam pasar perkreditan mikro menempati tempat kedua setelah BRI-unit desa sebesar 46\% dari KSP/USP dengan pangsa sekitar $31 \%$. Dengan demikian walaupun program pemerintah cukup gencar dan menimbulkan distorsi pada pertumbuhan kemandirian koperasi, tetapi hanya menyentuh sebagian dari populasi koperasi yang 
NIAGAWAN Vol 7 No 2 Juli 2018

ada. Sehingga pada dasarnya masih besar elemen untuk tumbuhnya kemandirian koperasi.

1. Memasuki tahun 2000 posisi koperasi Indonesia pada dasarnya justru didominasi oleh koperasi kredit yang menguasai antara 55-60 persen dari keseluruhan aset koperasi. Sementara itu dilihat dari populasi koperasi yang terkait dengan program pemerintah hanya sekitar $25 \%$ dari populasi koperasi atau sekitar $35 \%$ dari populasi koperasi aktif. Pada akhir-akhir ini posisi koperasi dalam pasar perkreditan mikro menempati tempat kedua setelah BRI-unit desa sebesar 46\% dari KSP/USP dengan pangsa sekitar $31 \%$. Dengan demikian walaupun program pemerintah cukup gencar dan menimbulkan distorsi pada pertumbuhan kemandirian koperasi, tetapi hanya menyentuh sebagian dari populasi koperasi yang ada. Sehingga pada dasarnya masih besar elemen untuk tumbuhnya kemandirian koperasi.

2. Potensi koperasi pada saat ini sudah mampu untuk memulai gerakan koperasi yang otonom, namun fokus bisnis koperasi harus diarahkan pada ciri universalitas kebutuhan yang tinggi seperti jasa keuangan, pelayanan infrastruktur serta pembelian bersama. Dengan otonomi selain peluang untuk memanfaatkan potensi setempat juga terdapat potensi benturan yang harus diselesaikan di tingkat daerah. Dalam hal ini konsolidasi potensi keuangan, pengembangan jaringan informasi serta pengembangan pusat inovasi dan teknologi merupakan kebutuhan pendukung untuk kuatnya kehadiran koperasi. Pemerintah di daerah dapat mendorong pengembangan lembaga penjamin kredit di daerah..

\section{METODE PENELITIAN}

Metode penelitian adalah cara ilmiah untuk mendapatkan data dengan tujuan dan kegunaan tertentu. Metode penelitian juga dapat diartikan sebagai cara-cara yang digunakan untuk mengumpulkan dan menganalisis data yang dikembangkan untuk memperoleh pengetahuan dengan menggunakan prosedur yang reliabel dan terpercaya. Dalam penelitian ini digunakan penelitian kepustakaan.

Studi kepustakaan adalah kegiatan untuk menghimpun informasi yang relevan dengan topik atau masalah yang menjadi obyek penelitian. Informmasi tersebut dapat diperoleh dari buku-buku, karya ilmiah, tesis, disertasi, ensiklopedia, internet, dan sumber-sumber lain. Dengan melakukan studi kepustakaan, peneliti dapat memanfaatkan semua informasi dan pemikiran-pemikiran yang relevan dengan penelitinya.

\section{HASIL DAN PEMBAHASAN \\ Perkembangan Koperasi di Indonesia}

Koperasi merupakan lembaga ekonomi yang cocok diterapkan di Indonesia. Karena sifat masyarakatnya yang kekeluargaan dan kegotongroyongan, sifat inilah yang sesuai dengan azas koperasi saat ini. Sejak lama bangsa Indonesia telah mengenal kekeluargaan dan kegotongroyongan yang dipraktekkan oleh nenek moyang bangsa Indonesia. Kebiasaan yang bersifat nonprofit ini, merupakan input untuk Pasal 33 ayat 1 UUD 1945 yang dijadikan dasar/pedoman pelaksanaan Koperasi. Kebiasaan-kebiasaan nenek moyang yang turuntemurun itu dapat dijumpai di berbagai daerah di Indonesia di antaranya adalah Arisan untuk daerah Jawa Tengah dan Jawa Timur, paketan, mitra cai dan ruing mungpulung daerah Jawa Barat, Mapalus di daerah Sulawesi Utara, kerja sama pengairan yang terkenal dengan Subak untuk daerah Bali, dan Julo-julo untuk daerah Sumatra Barat merupakan sifat-sifat hubungan sosial, nonprofit dan menunjukkan usaha atau kegiatan atas dasar kadar kesadaran berpribadi dan kekeluargaan. Bentuk-bentuk ini yang lebih bersifat kekeluargaan, kegotongroyongan, hubungan social, nonprofit dan kerjasama disebut Pra Koperasi. Pelaksanaan yang bersifat pra-koperasi terutama di pedesaan masih dijumpai, meskipun arus globlisasi terus merambat kepedesaan.

Kemajuan ilmu pengetahuan dan teknologi pada pertengahan abad ke-18 telah mengubah wajah dunia. Berbagai penemuan di bidang teknologi ( revolusi industri ) melahirkan tata dunia ekonomi baru. Tatanan dunia ekonomi menjadi terpusat pada keuntungan perseorangan, yaitu kaum pemilik modal ( kapitalisme ). Kaum kapitalis atau pemilik modal memanfaatkan penemuan baru tersebutdengan sebaik-baiknya untuk memperkaya dirinya dan memperkuat kedudukan ekonominya. Hasrat serakah ini melahirkan persaingan bebas yang tidak terbatas. Sistem ekonomi kapitalis / liberal memberikan keuntungan yang sebesar-besarnya kepada pemilik modal dan melahirkan kemelaratan dan kemiskinan bagi masyarakat ekonomilemah. 
Dalam kemiskinan dan kemelaratan ini, muncul kesadaran masyarakat untuk memperbaiki nasibnya sendiri dengan mendirikan koperasi. Pada tahun 1844 lahirlah koperasi pertama di Inggris yang terkenal dengan nama Koperasi Rochdale di bawah pimpinan Charles Howart. Di Jerman, Frederich Willhelm Raiffeisen dan Hermann Schulze memelopori Koperasi Simpan Pinjam. Di Perancis, muncul tokoh-tokoh kperasi seperti Charles Fourier, Louis Blance, dan Ferdinand Lassalle. Demikian pula di Denmark. Denmark menjadi Negara yang paling berhasil di dunia dalam mengembangkan ekonominya melalui koperasi.

Kemajuan industri di Eropa akhirnya meluas ke Negara-negara lain, termasuk Indonesia. Bangsa Eropa mulai mengembangkan sayap untuk memasarkan hasil industri sekaligus mencari bahan mentah untuk industri mereka. Pada permulaannya kedatangan mereka murni untuk berdagang. Nafsu serakah kaum kapitalis ini akhirnya berubah menjadi bentuk penjajahan yang memelaratkan masyarakat. Bangsa Indonesia, misalnya dijajah oleh Belanda selama 3,5 abad dan setelah itu dijajah Jepang selama 3,5 tahun. Selama penjajahan, bangsa Indonesia berada dalam kemelaratan dan kesengsaraan. Penjajah melakukan penindsan terhadap rakyat dan mengeruk hasil yang sebanyak-banyaknya dari kekayaan alam Indonesia. Penjajahan menjadikan perekonomian Indonesia terbelakang. Masyarakat diperbodoh sehingga dengan mudah menjadi mangsa penipuan dan pemerasan kaum lintah darat, tengkulak, dan tukang ijon. Koperasi memang lahir dari penderitaan sebagai mana terjadi di Eropa pertengahan abad ke-18. Di Indonesia pun koperasi ini lahir sebagai usaha memperbaiki ekonomi masyarakat yang ditindas oleh penjajah pada masa itu.

Untuk mengetahui perkembangan koperasi di Indonesia, sejarah perkembangan koperasi Indonesia secara garis besar dapat dibagi dalam " dua masa ", yaitu masa penjajahan dan masa kemerdekaan.

\section{Koperasi di Indonesia sebelum merdeka}

Pada zaman penjajahan banyak rakyat Indonesia yang hidup menderita, tertindas, dan terlilit hutang dengan para rentenir. Beberapa tahap penting mengenai perkembangan koperasi di Indonesia :
NIAGAWAN Vol 7 No 2 Juli 2018

Karena hal tersebut pada tahun 1896, patih purwokerto yang bernama R. Aria Wiriaatmadja mendirikan koperasi kredit untuk membantu para rakyat yang terlilit hutang.

Lalu pada tahun 1908, perkumpulan Budi Utomo memperbaiki kesejahteraan rakyat melalui koperasi dan pendidikan dengan mendirikan koperasi rumah tangga, yang dipelopori oleh Dr.Sutomo dan Gunawan Mangunkusumo.

Setelah Budi Utomo sekitar tahun 1911, Serikat Dagang Islam (SDI) dipimpin oleh H.Samanhudi dan H.O.S Cokroaminoto mempropagandakan cita-cita toko koperasi (sejenis waserda KUD), hal tersebut bertujuan untuk mengimbangi dan menentang politik pemerintah kolonial belanda yang banyak memberikan fasilitas dan menguntungkan para pedagang asing. namun pelaksanaan baik koperasi yang dibentuk oleh Budi Utomo maupun SDI tidak dapat berkembang dan mengalami kegagalan, hal ini karena lemahnya pengetahuan perkoperasian, pengalaman berusaha, kejujuran dan kurangnya penelitian tentang bentuk koperasi yang cocok diterapkan di Indonesia.

Upaya pemerintah kolonial belanda untuk memecah belah persatuan dan kesatuan rakyat Indonesia ternyata tidak sebatas pada bidang politik saja, tapi kesemua bidang termasuk perkoperasian. Hal ini terbukti dengan adanya undang-undang koperasi pada tahun 1915, yang disebut "Verordening op de Cooperative Vereenigingen" yakni undang-undang tentang perkumpulan koperasi yang berlaku untuk segala bangsa, jadi bukan khusus untuk Indonesia saja. Undang-undang koperasi tersebut sama dengan undang-undang koperasi di Nederland pada tahun 1876 (kemudian diubah pada tahun 1925), dengan perubahan ini maka peraturan koperasi di indonesia juga diubah menjadi peraturan koperasi tahun 1933 LN no.108. Di samping itu pada tahun 1927 di Indonesia juga mengeluarkan undang-undang no.23 tentang peraturanperaturan koperasi, namun pemerintah belanda tidak mencabut undang-undang tersebut, sehingga terjadi dualisme dalam bidang pembinaan perkoperasian di Indonesia.

Meskipun kondisi undang-undang di indonesia demikian, pergerakan dan upaya bangsa indonesia untuk melepaskan diri dari kesulitan ekonomi tidak pernah berhenti, pada tahun 1929, Partai Nasionalis Indonesia (PNI) di bawah pimpinan Ir.Soekarno mengobarkan 
NIAGAWAN Vol 7 No 2 Juli 2018

semangat berkoperasi kepada kalangan pemuda. Pada periode ini sudah terdaftar 43 koperasi di Indonesia.

Pada tahun 1930, dibentuk bagian urusan koperasi pada kementrian Dalam Negeri di mana tokoh yang terkenal masa itu adalah R.M.Margono Djojohadikusumo. Lalu pada tahun 1939, dibentuk Jawatan Koperasi dan Perdagangan dalam negeri oleh pemerintah. Dan pada tahun 1940, di Indonesia sudah ada sekitar 656 koperasi, sebanyak 574 koperasi merupakan koperasi kredit yang bergerak di pedesaan maupun di perkotaan.

Setelah itu pada tahun 1942, pada masa kedudukan jepang keadaan perkoperasian di Indonesia mengalami kerugian yang besar bagi pertumbuhan koperasi di Indonesia, hal ini disebabkan pemerintah jepang mencabut undang-undang no.23 dan menggantikannya dengan kumini (koperasi model jepang) yang hanya merupakan alat mereka untuk mengumpulkan hasil bumi dan barang-barang kebutuhan jepang.

\section{Koperasi di Indonesia setelah merdeka}

Keinginan dan semangat untuk berkoperasi yang hancur akibat politik pada masa kolonial belanda dan dilanjutkan oleh sistem kumini pada zaman penjajahan jepang, lambat laun setelah Indonesia merdeka kembali menghangat. Apalagi dengan adanya UndangUndang Dasar Republik Indonesia tahun 1945, pada pasal 33 yang menetapkan koperasi sebagai soko guru perekonomian Indonesia, maka kedudukan hukum koperasi di Indonesia benarbenar menjadi lebih mantap. Dan sejak saat itu Moh.Hatta sebagai wakil presiden Republik Indonesia lebih intensif mempertebal kesadaran untuk berkoperasi bagi bangsa Indonesia, serta memberikan banyak bimbingan dan motivasi kepada gerakan koperasi agar meningkatkan cara usaha dan cara kerja, atas jasa-jasa beliau lah maka Moh.Hatta diangkat sebagai Bapak Koperasi Indonesia.

Beberapa kejadian penting yang mempengaruhi perkembangan koperasi di Indonesia :

1. Pada tanggal 12 Juli 1947, dibentuk SOKRI (Sentral Organisasi Koperasi Rakyat Indonesia) dalam Kongres Koperasi Indonesia I di Tasikmalaya, sekaligus ditetapkannya sebagai Hari Koperasi Indonesia.

2. Pada tahun 1960 dengan Inpres no.2, koperasi ditugaskan sebagai badan penggerak yang menyalurkan bahan pokok bagi rakyat. Dengan inpres no.3, pendidikan koperasi di Indonesia ditingkatkan baik secara resmi di sekolah-sekolah, maupun dengan cara informal melalui siaran media masa,dll yang dapat memberikan informasi serta menumbuhkan semangat berkoperasi bagi rakyat.

3. Lalu pada tahun 1961, dibentuk Kesatuan Organisasi Koperasi Seluruh Indonesia (KOKSI).

4. Pada tanggal 2-10 Agustus 1965, diadakan (Musyawarah Nasional Koperasi) MUNASKOP II yang mengesahkan Undang-Undang koperasi no.14 tahun 1965 di Jakarta.

Koperasi di Indonesia pada zaman orde baru hingga sekarang. Tampilan orde baru dalam memimpin negeri ini membuka peluang dan cakrawala baru bagi pertumbuhan dan perkembangan perkoperasian di Indonesia, dibawah kepemimpinan Jenderal Soeharto. Ketetapan MPRS no.XXIII membebaskan gerakan koperasi dalam berkiprah.

Berikut beberapa kejadian perkembangan koperasi di Indonesia pada zaman orde baru hingga sekarang :

a. Pada tanggal 18 Desember 1967, Presiden Soeharto mensahkan Undang-Undang koperasi no.12 tahun 1967 sebagai pengganti Undang-Undang no.14 tahun 1965.

b. Pada tahun 1969, disahkan Badan Hukum terhadap badan kesatuan Gerakan Koperasi Indonesia (GERKOPIN).

c. Lalu pada tanggal 9 Februari 1970, dibubarkannya GERKOPIN dan sebagai penggantinya dibentuk Dewan Koperasi Indonesia (DEKOPIN).

d. Pada tanggal 21 Oktober 1992, disahkan Undang-Undang no.25 tahun 1992 tentang perkoperasian, undang-undang ini merupakan landasan yang kokoh bagi koperasi Indonesia di masa yang akan datang.

e. Masuk tahun 2000an hingga sekarang perkembangan koperasi di Indonesia cenderung jalan di tempat.

Keberhasilan koperasi di dalam melaksanakan peranannya perlu diperhatikan faktor-faktor sebagai berikut :

1. Kemampuan menciptakan posisi pasar dan pengawasan harga yang layak dengan cara: 
a. Bertindak bersama dalam menghadapi pasar melalui pemusatan kekuatan bersaing dari anggota

b. Memperpendek jaringan pemasaran

c. Memiliki manajer yang cukup terampil berpengetahuan luas dan memiliki idealisme

d. Mempunyai dan meningkatkan kemampuan koperasi sebagai satu unit usaha dalam mengatur jumlah dan kualitas barang-barang yang dipasarkan melalui kegiatan pergudangan, penelitian kualitas yang cermat dan sebagainya.

2. Kemampuan koperasi untuk menghimpun dan menanamkan kembali modal, dengan cara pemupukan pelbagai sumber keuangan dari sejumlah besar anggota.

3. Penggunaan faktor-faktor produksi yang lebih ekonomis melalui pembebanan biaya overhead yang lebih, dan mengusahakan peningkatan kapasitas yang pada akhirnya dapat menghasilkan biaya per unit yang relatif kecil.

4. Terciptanya keterampilan teknis di bidang produksi, pengolahan dan pemasaran yang tidak mungkin dapat dicapai oleh para anggota secara sendiri-sendiri.

5. Pembebasan resiko dari anggota-anggota kepada koperasi sebagai satu unit usaha, yang selanjutnya hal tersebut kembali ditanggung secara bersama di antara anggota-anggotanya.

6. Pengaruh dari koperasi terhadap anggotaanggotanya yang berkaitan dengan perubahan sikap dan tingkah laku yang lebih sesuai dengan perubahan tuntutan lingkungan di antaranya perubahan teknologi, perubahan pasar dan dinamika masyarakat.

Dalam rangka pengembangan KUD mandiri telah diterbitkan INSTRUKSI MENTERI KOPERASI No. 04/Ins/M/VI/1988 tentang Pedoman Pembinaan dan Pengembangan KUD mandiri. Pembinaan dan Pengembangan KUD mandiri diarahkan:

1. Menumbuhkan kemampuan perekonomian masyarakat khususnya di pedesaan.

2. Meningkatkan peranannya yang lebih besar dalam perekonomian nasional.

3. Memberikan manfaat yang sebesar-besarnya dalam peningkatan kegiatan ekonomi dan pendapatan yang adil kepada anggotanya.
Ukuran-ukuran yang digunakan untuk menilai apakah suatu KUD sudah mandiri atau belum adalah sebagai berikut :

1. Mempunyai anggota penuh minimal $25 \%$ dari jumlah penduduk dewasa yang memenuhi persyaratan keanggotaan KUD di daerah kerjanya.

2. Dalam rangka meningkatkan produktifitas usaha anggotanya maka pelayanan kepada anggota minimal $60 \%$ dari volume usaha KUD secara keseluruhan.

3. Minimal tiga tahun buku berturut-turut RAT dilaksanakan tepat pada waktunya sesuai petunjuk dinas.

4. Anggota Pengurus dan Badan Pemeriksa semua berasal dari anggota KUD dengan jumlah maksimal untuk pengurus 5 orang dan Badan Pemeriksa 3 orang.

5. Modal sendiri KUD minimal Rp. 25,- juta.

6. Hasil audit laporan keuangan layak tapa catatan (unqualified opinion).

7. Batas toleransi devisa usaha terhadap rencana usaha KUD (Program dan Non Program) sebesar $20 \%$.

8. Total volume usaha harus proporsional dengan jumlah anggota, dengan minimal rata-rata Rp. 250.000,- per anggota per tahun.

9. Pendapatan kotor minimal dapat menutup biaya berdasarkan prinsip efisiensi.

10. Sarana usaha layak dan dikelola sendiri

11. Tidak ada penyelewengan dan manipulasi yang merugikan KUD oleh Pengelola KUD

12. Tidak mempunyai tunggakan

Keberhasilan atau kegagalan koperasi ditentukan oleh keunggulan komparatif koperasi. Hal ini dapat dilihat dalam kemampuan koperasi berkompetisi memberikan pelayanan kepada anggota dan dalam usahanya tetap hidup (survive) dan berkembang dalam melaksanakan usaha. Pengalaman empiris di mancanegara dan di negeri kita sendiri menunjukkan bahwa struktur pasar dari usaha koperasi mempengaruhi performance dan success koperasi (Ismangil, 1989).

\section{Faktor Penghambat Koperasi di Indonesia}

Perkembangan koperasi masih menghadapi masalah-masalah baik di bidang kelembagaan maupun di bidang usaha koperasi itu sendiri. Masalah-masalah tersebut dapat bersumber dari dalam koperasi sendiri maupun dari luar. Masalah kelembagaan koperasi juga dapat dikelompokkan dalam masalah intern 
maupun masalah ekstern. Masalah intern mencakup masalah keanggotaan, kepengurusan, pengawas, manajer, dan karyawan koperasi. Sedangkan masalah ekstern mencakup hubungan koperasi dengan bank, dengan usaha-usaha lain, dan juga dengan instansi pemerintah.

\section{Dari Sisi Kelembagaan Koperasi}

Masalah Internal :

\section{Keanggotaan dalam Koperasi}

Keadaan keanggotaan ditinjau dari segi kuantitas tercermin dari jumlah anggota yang semakin lama semakin berkurang. Masalahnya kenggotaan koperasi yang ada sekarang belum menjangkau bagian terbesar dari masyarakat. Ditinjau dari segi kualitas masalah keaggotaan koperasi tercermin dalam :

a. Tingkat pendidikan mereka yang pada umumnya masih rendah

b. Ketrampilan dan keahlian yang dimiliki oleh para anggota terbatas

c. Sebagian dari anggota belum menyadari hak dan kewajiban mereka sebagai anggota. Kebanyakan anggota koperasi belum menyadari bahwa koperasi merupakan suatu wadah usaha yang dimaksudkan untuk meningkatkan kegiatan ekonomi dan kesejahteraan mereka. Sebaiknya dalam kelompok tersebut harus ada tokoh yang berfungsi sebagai sebagai penggerak organisatoris untuk menggerakkan koperasi kearah sasaran yang benar.

d. Partisipasi mereka dalam kegiatan organisasi juga masih harus ditingkatkan. Apabila suatu koperasi mengadakan Rapat Anggota Tahunan (RAT) banyak anggotanya yang tidak hadir. Akibatnya keputusan-keputusan yang dihasilkan tidak mereka rasakan sebagai keputusan yang mengikat.

e. Banyaknya anggota yang tidak mau bekerjasama dan mereka juga memiliki banyak utang kepada koperasi, hal ini menyebabkan modal yang ada dikoperasi semakin berkurang.

\section{Pengurus Koperasi}

Dalam hal kepengurusan juga dihadapi kelemahan-kelemahan yang sama. masalah yang menjadi penghambat berkembangnya koperasi dari sisi pengurus adalah:

a. Pengetahuan, ketrampilan, dan kemampuan anggota pengurusnya masih belum memadai
NIAGAWAN Vol 7 No 2 Juli 2018

b. Pengurus belum mampu melaksanakan tugas mereka dengan semestinya.

c. Pengurus kurang berdedikasi terhadap kelangsungan hidup koperasi. Ini berarti bahwa kepribadian dan mental pengurus, pengawas, manajer belum berjiwa koperasi sehingga harus diperbaiki lagi.

d. Pengurus kadang-kadang tidak jujur

e. Masih ada koperasi yang anggota pengurusnya kurang berusaha untuk menigkatkan pengetahuan dan ketrampilannya. Kursus-kursus yang diselenggarakan untuk pengurus koperasi sering tidak mereka hadiri.

f. Dalam kepengurusan koperasi sampai saat ini masih belum ada pembagian tugas yang jelas.

g. Pengurus koperasi kebanyakan yang sudah lanjut usia dan para tokoh masyarakat yang sudah memiliki jabatan ditempat lain, sehingga perhatiannya terhadap koperasi berkurang.

h. Pegurus masih belum mampu berkoordinasi dengan anggota, manajer, pengawas, dan instansi pemerintah dengan baik

3. Pengawas Koperasi

Anggota dari badan pengawas koperasi banyak yang belum berfungsi. Hal ini di disebabkan oleh:

a. Kemampuan anggoota pengawas yang belum memadai, terlebih jika dibandingkan dengan semakin meningkatnya usaha koperasi

b. Di pihak lain, pembukuan koperasi biasanya belum lengkap dan tidak siap untuk diperiksa.

c. Pemeriksaan yang dilakukan oleh petugas koperasi sekunder dan kantor koperasi juga belum banyak membantu perkembangan kemampuan anggota pengawas ataupun peningkatan pembukuan koperasi. Pemeriksaan yang mereka lakukan terutama mengarah pada kepentingan permohonan kredit.

Masalah Eksternal :

1. Iklim yang mendukung pertumbuhan koperasi belum selaras dengan kehendak anggota koperasi, seperti kebijakan pemerintah yang belem jelas dan efektif untuk koperasi, sistem prasarana, pelayanan, pendidikan, dan penyuluhan. 
2. Banyaknya badan usaha lain yang bergerak pada bidang usaha yang sama dengan koperasi.

3. Kurangnya fasilitas-fasilitas yang dapat menarik perhatian masyarakat dan masih banyaknya masyarakat yang tidak mempercayai koperasi.

\section{Dari Sisi Bidang Usaha Koperasi}

Masalah usaha koperasi dapat digambarkan sebagai berikut. Ada koperasi yang manajer dan karyawannya belum memenuhi harapan. Di antara mereka ada yang belum dapat bekerja secara profesional, sesuai dengan peranan dan tugas operasi yang telah ditetapkan. Masih ada administrasi koperasi yang belum menggunakan prinsip-prinsip pembukuan dengan baik. Sistem informasi majemen koperasi mesih belum berkembang sehingga pengambilan keputusan belum didukung dengan informasi yang cukup lengkap dan dapat diandalkan.

Di samping itu masih ada manajer yang kurang mempunyai kemampuan sebagai wirausaha. Di antara mereka bahkan masih ada yang kurang mampu untuk menyusun rencana, program, dan kegiatan usaha. Padahal mereka harus memimpin dan menggerakkan karyawan untuk melaksanakan rencana, program, dan kegiatan usaha yang ditentukan. Penilaian terhadap keadaan serta mengadakan penyesuaian rencana, program, dan kegiatan usaha setiap kali ada perkembangan dalam keadaan yang dihadapainya.

Dari sisi produksi, koperasi sering mengalami kesulitan untuk memperoleh bahan baku. Salah satu bahan baku pokok yang sulit diperoleh adalah modal. Dalam hal kualitas, output koperasi tidak distandardisasikan, sehingga secara relatif kalah dengan output industri besar. dalam banyak kasus, output koperasi (dan UKM) tidak memiliki keunggulan komparatif sehingga sulit untuk dipasarkan.

Secara umum koperasi harus menghadapi kelemahannya sebagai berikut :

- Pembinaan hubungan antara alat perlengkapan koperasi, khususnya antara pengurus dan manajer, yang masih perlu ditingkatkan. Hal ini antara lain mengingat perlunya koordinasi yang mantab dan pembagian tugas serta tanggung jawab yang jelas. Harus dihindarkan apabila ada pengurus yang mengambil wewenang manajer melaksanakan tugas operasional.
- Kebijaksanaan dan program kerja koperasi masih cenderung timbul sebagai prakarsa pemerintah. Programprogram yang diarahkan untuk memenuhi kebutuhan anggota masih ada yang belum sepenuhnya dipadukan dengan program-program yang timbul dari prakarsa pemerintah. Keputusan koperasi yang mandiri masih belum dapat berkembang.

- Organisasi tingkat sekunder, seperti Pusat Koperasi dan Induk koperasi, tampak belum sepenuhnya dapat memberikan pelayanan kepada koperasi primer, khususnya meningkatkan kemampuan dalam bidang organisasi, administrasi, dan manjemen.

- Kerja sama koperasi dan lembaga nonkoperasi telah ada yang berlangsung atas landasan saling menguntungkan antara kedua belah pihak. Tetapi, apabila kurang hati-hati dalam membinannya ada kerjasama yang cenderung mengarah pada hilangnya kemandirian koperasi.

- Kemampuan pemupukan modal usaha yang bersumber dari anggota dan hasil usaha koperasi, walaupun cukup memadai perkembangannya namun ternyata masih sangat terbatas.

- Dalam usaha memperoleh kredit dari bank, koperasi masih menghadapi kesulitan untuk memenuhi persyaratanyang ditentukan. Demikianlah, maka pemupukan modal koperasi walaupun cepat perkembangannya hasilnya masih terbatas juga.

- Keterpaduan gerak, pengertian, pembinaan, dan pengawasan terhadap gerakan koperasi dari berbagai instansi masih perlu ditingkatkan.

- Masalah lain yang dihadapi dalam pelaksanaan pembinaan koperasi pada tingkat perkembangan seperti sekarang ini adalah masih kurangnya petugas pembina koperasi, baik dalam jumlah maupun mutunya.

- Masalah permodalan, penguasaan teknologi, akses informasi, permasalahan pemasaran, dan perlindungan hukum. 
- Kurangnya dana sehingga fasilitasfasilitas yang sudah ada tidak dirawat, hal ini menyebabkan koperasi tertinggal karena kemajan teknologi yang sangat cepat.

Masalah yang dihadapi koperasi akan semakin meluas jika tidak ditangani sesegera mungkin. Sebelum melakukan tindakan pemecahan masalah langkah awal yang harus kita lakukan adalah menganalisa penyebab terjadinya masalah. Setelah kita mengetahui akar permasalahannya dimana barulah kita dapat melakukan langkah konkrit yang diharapkan dapat memecahkan masalah yang sedang dihadapi. Dalam penyelesaian masalah ini dibutuhkan keterlibatan semua elemen masyarakat baik pemerintah dan masayarakat itu sendiri.

Berikut ini masalah yang dihadapi koperasi secara umum dan cara mengatasi permasalahan tersebut, yaitu :

\section{Koperasi jarang peminatnya}

Koperasi jarang peminatnya dikarenakan ada pandangan yang berkembang dalam masyarakat bahwa koperasi adalah usaha bersama yang diidentikkan dengan masyarakat golongan menengah ke bawah. Dari sinilah perlu adanya sosialisasi kepada masyarakat tentang koperasi. Dengan adanya sosialisasi diharapkan pengetahuan masyarakat tentang koperasi akan bertambah. Masyarakat dapat mengetahui bahwa sebenarnya koperasi merupakan ekonomi rakyat yang dapat menyejahterakan anggotanya. Sehingga mereka berminat untuk bergabung.

2. Kualitas Sumber Daya yang terbatas

Koperasi sulit berkembang disebabkan oleh banyak faktor, yaitu bisa disebabkan Sumber Daya Manusia yang kurang. Sumber daya manusia yang dimaksud adalah pengurus koperasi. Seperti yang sering dijumpai, pengurus koperasi biasanya merupakan tokoh masyarakat sehingga dapat dikatakan rangkap jabatan, kondisi seperti inilah yang menyebabkan ketidakfokusan terhadap pengelolaan koperasi itu sendiri. Selain rangkap jabatan biasanya pengurus koperasi sudah lanjut usia sehingga kapasitasnya terbatas. Perlu dilakukan pengarahan tentang koperasi kepada generasi muda melalui pendidikan agar mereka dadat berpartisipasi dalam koperasi.Partisipasi merupakan faktor yang penting dalam mendukung perkembangan koperasi. Partisipasi akan meningkatkan rasa tanggung jawab sehingga dapat bekerja secara efisien dan efektif.
3. Banyaknya pesaing dengan usaha yang sejenis

Pesaing merupakan hal yang tidak dapat dielakkan lagi, tetapi kita harus mengetahui bagaimana menyikapinya. Bila kita tidak peka terhadap lingkungan (pesaing) maka mau tidak mau kita akan tersingkir. Bila kita tahu bagaimana menyikapinya maka koperasi akan survive dan dapat berkembang. Dalam menanggapi pesaing kita harus mempunyai trik - trik khusus, trik - trik/ langkah khusus tersebut dapat kita lakukan dengan cara melalui harga barang/jasa, sistem kredit dan pelayanan yang maksimum. Mungkin koperasi sulit untuk bermain dalam harga, tapi hal ini dapat dilakukan dengan cara sistem kredit, yang pembayarannya dapat dilakukan dalam waktu mingguan ataupun bulanan tergantung perjanjian. Dengan adanya hal seperti ini diharapkan dapat menarik perhatian masyarakat untuk menjadi anggota.

\section{Keterbatasan Modal}

Pemerintah perlu memberikan perhatian kepada koperasi yang memang kesulitan dalam masalah permodalan. Dengan pemberian modal koperasi dapat memperluas usahanya sehingga dapat bertahan dan bisa berkembang. Selain pemerintah, masyarakat merupakan pihak yang tak kalah pentingnya, dimana mereka yang memiliki dana lebih dapat menyimpan uang mereka dikoperasi yang nantinya dapat digunakan untuk modal koperasi.

5. Partisipasi anggota

Sebagai anggota dari koperasi seharusnya mereka mendukung program-program yang ada di koperasi dan setiap kegiatan yang akan dilakukan harus melalui keputusan bersama dan setiap anggota harus mengambil bagian di dalam kegiatan tersebut.

\section{Perhatian pemerintah}

Pemerintah harus bisa mengawasi jalannya kegiatan koperasi sehingga bila koperasi mengalami kesulitan, koperasi bisa mendapat bantuan dari pemerintah, misalnya saja membantu penyaluran dana untuk koperasi.Akan tetapi pemerintah juga jangan terlalu mencampuri kehidupan koperasi terutama halhal yang bersifat menghambat pertumbuhan koperasi. Pemerintah hendaknya membuat kenijakan-kebijakan yang dapat membantu perkembangan koperasi.

7. Manajemen koperasi

Dalam pelaksanaan koperasi tentunya memerlukan manajemen, baik dari bentuk 
perencanaan, pengorganisasian, pengarahan, dan pengawasan. Karena hal ini sangat berfungsi dalam pengambilan keputusan tetapi tidak melupakan partisipasi dari anggota.

Apabila semua kegiatan koperasi bisa dijalankan dengan baik dan setiap anggota mau mengambil bagian di dalam kegiatan koperasi serta perhatian pemerintah dapat memberikan motifasi yang baik, koperasi pasti dapat berjalan dengan lancar.

\section{KESIMPULAN DAN SARAN}

Koperasi di Indonesia tentulah terjadi yang namanya pasang surut di dalam dunia koperasi , oleh karena itu marilah kita meningkatkan kesadaran dari diri kita masing masing dalam usaha untuk meningkatkan koperasi di Indonesia dengan cara meningkatkan kinerja anggota koperasi dengan cara memberikan training atau pelatihan kepada anggota koperasi terus kita juga bisa memodifikasi produk yang ada, dengan memodifikasi produk-produk yang ada dikoperasi , kiranya akan meningkatkan selera masyarakat sehingga tertarik untuk mengkonsumsi produk dari koperasi tersebut dengan menyesuaikan dengan perkembangan zaman dari tahun ke tahun dan juga memperbaiki koperasi secara menyeluruh, kita harus menjadikan koperasi yang ada Indonesia ini sebagai koperasi yang baik dan mari kita memberi perubahan yang ada untuk lebih mensejahterkan koperasi Indonesia agar menjadi lebih baik lagi.

\section{REFERENSI}

Anhari. Ally Sultan Al. 2010. “analisis laporan keuangan pada koprasi”. Skripsi. Surakarta

Arifin, Johar. 2002. Manajemen koprasi. Jakarta: Gramedia

Endang. 2014. Masalah dan solusi dalam memajukan koprasi. Artiel.

Chianiago, Arifinal. 1987. Perkoprasian Indonesia. Bandung: Angkasa
NIAGAWAN Vol 7 No 2 Juli 2018

Sujadi. 2003. Manajeman Koprasi.

Surakarta: fakultas ekonomi UMS

Virgina, Tirsa. 2011. Koprasi Indonesia:

Potret dan tantangan. Jurnal.

Undang-undang Republik Indonesia Tentang Perkoprasian 